\title{
PRESENCE OF A PHYTOPLASMA ASSOCIATED WITH WITCHES' BROOM DISEASE IN Ugni molinae Turcz. AND Gaultheria phillyreifolia (Pers.) Sleumer DETERMINED BY DAPI, PCR, AND DNA SEQUENCING
}

\author{
Nolberto Arismendi S. ${ }^{1}$, Nancy Andrade S. ${ }^{*}$, Ricardo Riegel Sch. ${ }^{1}$, and Roberto Carrillo Ll. ${ }^{1}$
}

\begin{abstract}
Murta (Ugni molinae Turcz.) and common chaura (Gaultheria phillyreifolia (Pers.) Sleumer) are native species of Chile. Plants of both species have shown over-branching like witches' broom. The causal agents of these symptoms in many plants are phytoplasma. To verify the presence of these microorganisms, DAPI (4',6-diamidino2-phenylindole) staining analysis and polymerase chain reaction (PCR) were performed in symptomatic and asymptomatic plants. Positive PCR samples were sequenced to identify the pathogens involved. In individuals of both species with witches' broom symptoms, DAPI staining showed fluorescent bodies in the phloem tissues, but not in asymptomatic plants. Verification by nested-PCR, phytoplasmatic DNA was amplified from diseased murta and chaura, but not in apparently healthy plants. Sequencing of amplified products allowed locating phytoplasma within the ash yellows group (16SrVII) and related to Candidatus phytoplasma fraxini. This is the first report of phytoplasma in Chilean native species. Considering the diversity of plant species infected by the ash yellows group suggests that $G$. phillyreifolia and $U$. molinae could be a phytoplasma reservoir for other economically important agricultural crops.
\end{abstract}

Key words: native shrubs, witches' broom, phytoplasma, microscopic and molecular tools.

\section{INTRODUCTION}

Murta (Ugni molinae Turcz., Myrtaceae) and common chaura (Gaultheria phillyreifolia (Pers.) Sleumer, Ericaceae) are native species of Chile that share a similar environment and distribution (between $34^{\circ}$ and $54^{\circ} \mathrm{S}$ lat) given that murta has been reported from the Maule Region to Aysén del General Carlos Ibáñez del Campo Region (Seguel and Torralbo, 2004) and chaura from the Maule Region to the Magallanes Region and the Chilean Antarctic (Donoso and Ramírez, 1997). Both species grow in varied conditions, invading deforested, marginal lands with low fertility, as part of the forest and prairie undergrowth and ecotones (Donoso and Ramírez, 1997; Seguel and Torralbo, 2004). Murta is considered a species with high agronomic and pharmaceutical potential, principally for its organoleptic, antioxidant, and analgesic attributes (Seguel and Torralbo, 2004; Delporte et al., 2007; Suwalsky et al., 2007). On the other hand, chaura is an ornamental species with little impact on the national market. There are few records of pests and diseases that

'Universidad Austral de Chile, Facultad de Ciencias Agrarias, Casilla 567, Valdivia, Chile. "Corresponding author (nandrade@uach.cl).

Received: 31 December 2008.

Accepted: 16 June 2009. can affect the development of both species. However, in murta and chaura plants, a strong reduction has been observed in the growth of shoots, causing leaves to develop abnormally, giving rise to over-branching that later dies. This type of symptomatology is known as witches' broom (Figure 1). The causal agents of this symptomatology can be varied (biotic and abiotic), but in the majority of cases, they have been related to phytoplasmas (Ghosh et al., 1999; Montano et al., 2001; Abou-Jawdah et al., 2002; Barros et al., 2002; Khan et al., 2002; Marcone et al., 2004; Al-Zadjalt et al., 2007).

Since their detection in the 1960s, a large number of diseases caused by phytoplasmas have been pointed out that affect hundreds of species worldwide (Lee et al., 2000; Bertaccini, 2007). The problem is not new in Chile since there are reports of some economically important crops (Hepp et al., 1998; Hepp and Vargas, 2002; Herrera and Madariaga, 2003; Fiore et al., 2007; Matus et al., 2008).

Phytoplasmas are obligate parasites that develop and reproduce asexually in the cytoplasma of their host cells (insects and plants) (Lee et al., 2000; Weintraub and Beanland, 2006). The fact that it is impossible to cultivate these microorganisms in vitro has limited their characterization or identification (Schneider et al., 1997). 

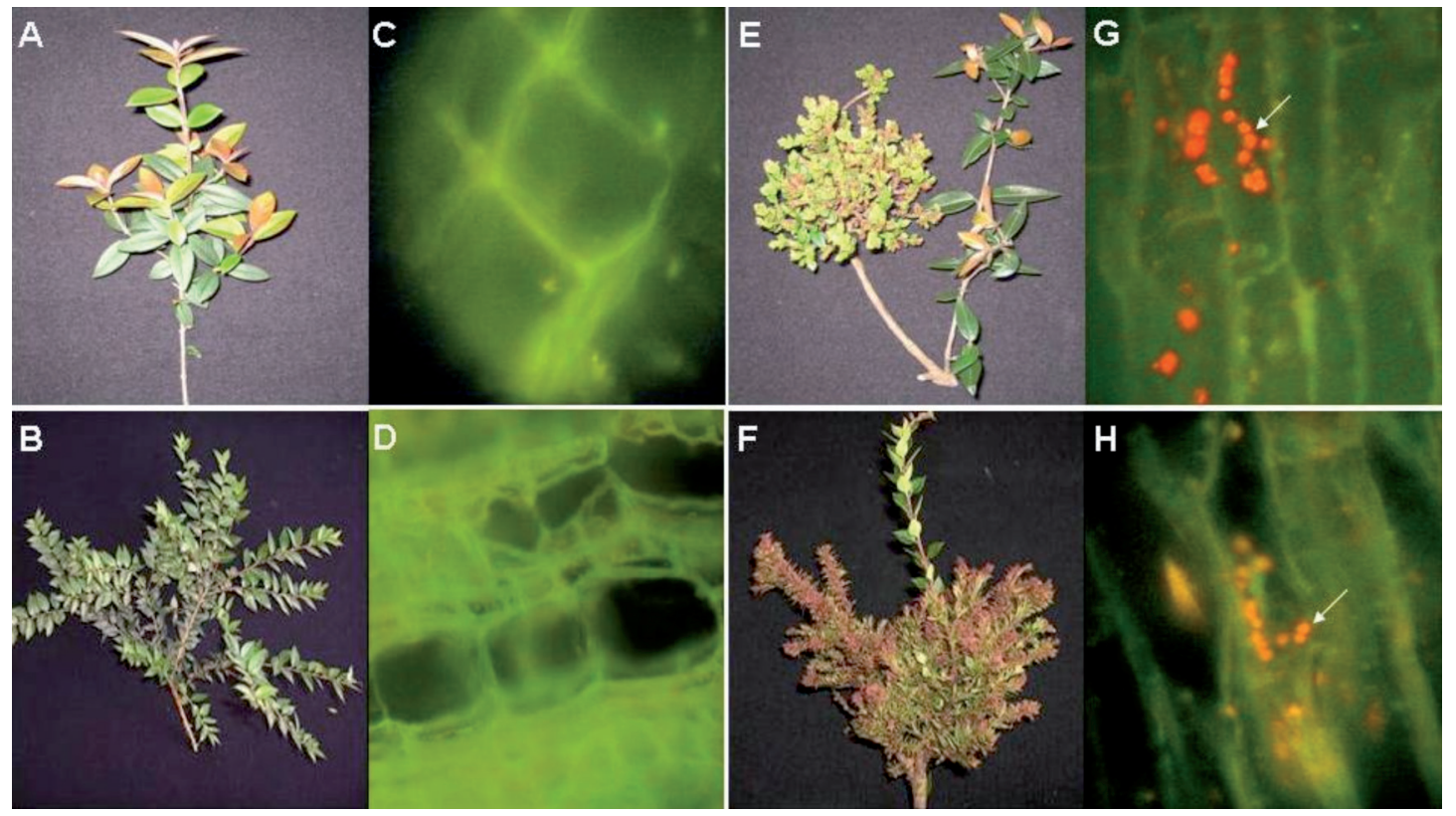

Figure 1. Asymptomatic plant tissues (control) of Ugni molinae (A); Gaultheria phillyreifolia (B); and their respective phloematic tissue staining with 4',6-diamidino-2-phenylindole (DAPI) (C and D); plant tissues with symptoms of witches' broom in $U$. molinae (E and G) and G. phillyreifolia $(\mathrm{F}$ and H). Fluorescent bodies $(\rightarrow)$ observed at 1000X.

Although microscopic techniques are still important for detecting phytoplasmas (Chapman et al., 2001; Fránová et al., 2007), molecular techniques are indispensable for determining taxonomic and phylogenetic relationships between phytoplasmas and other microorganisms (Lee et al., 1998; 2000). Universal primers, but specific for phytoplasmas, based on the regions of the 16S rRNA gene, intergenic region, and 23S rRNA gene are used widely for detecting these prokaryotes (Smart et al., 1996; Heinrich et al., 2001). Furthermore, sequencing of polymerase chain reaction (PCR) products and restriction fragment length polymorphism by PCR (PCRRFLP) are elementary techniques in the identification and characterization of phytoplasmatic groups (Lee at al., 1998; 2000). However, the majority of phytoplasma reports in Chile are based on electronic microscopy and DNA amplification with PCR using universal primers (Hepp et al., 1998; Villagra, 2001; Hepp and Vargas, 2002; Herrera and Madariaga, 2003). Only recent work has involved PCR-RFLP and DNA sequencing for a better identification of these prokaryotes (Fiore et al., 2007; Matus et al., 2008). The aim of this research was to determine the presence of phytoplasmas in $U$. molinae and G. phillyreifolia plants with symptoms of witches' broom. Microscopic techniques such as DAPI staining (4',6-diamidino-2-phenylindol) and molecular techniques such as specific amplification of phytoplasmatic DNA with PCR and subsequent sequencing were used.

\section{MATERIALS AND METHODS}

Samples of stems and petioles of young U. molinae and $G$. phillyreifolia plants with and without symptoms of witches' broom disease were taken from localities near the city of Valdivia (3949' S; 7312’ W), Chile. DAPI staining was based on the Romero (2001) protocol: $1 \mathrm{~cm}$ long pieces of symptomatic and asymptomatic stems and petioles were cut and put in $5 \%$ glutaraldehyde $(5 \mathrm{~mL}$ glutaraldehyde and $95 \mathrm{~mL} 0.1 \mathrm{M}$ buffer phosphate $\mathrm{pH}$ 6.8) for $15 \mathrm{~min}$. Samples were then washed in $0.1 \mathrm{M}$ buffer phosphate pH 6.9 for $5 \mathrm{~min}$. Immediately after, longitudinal cuts of 10 to 15 microns were made on the samples to be stained with DAPI staining (0.1 mg of 4',6-diamidino2-phenylindole in $100 \mathrm{~mL}$ of sterile water) for $20 \mathrm{~min}$. Finally, the preparations were observed with a fluorescent microscope (BP 450-490, FT 510 and LP 520 filters; Carl Zeiss Axiolab, New York, USA) with a UV light excitation longitude of 450-490 $\mathrm{nm}$ with an oil immersion lens $100 \mathrm{X}$ and ocular lenses $10 \mathrm{X}$ to achieve a maximum magnification of 1000X.

For genomic DNA extraction (plant and phytoplasma DNA), the protocol prepared by Lodhi et al. (1994) was followed along with the following modifications: 200 $\mathrm{mg}$ of each sample were ground in the presence of liquid nitrogen and dissolved in $500 \mu \mathrm{L}$ of CTAB-PVP $2 \%$ (Tris-HCl $100 \mathrm{mM}$ pH 8.0; NaCl $1.4 \mathrm{M}$; EDTA $20 \mathrm{mM}$ $\mathrm{pH} 8.0 ; 2 \% \mathrm{CTAB} w / \mathrm{v} ; 0.2 \%$ 2-mercaptoethanol v/v and 
$2 \%$ polyvinylpyrrolidone PVP40-50G w/v) extraction buffer (pre-heated at $60{ }^{\circ} \mathrm{C}$ ) and incubated at $65^{\circ} \mathrm{C}$ for 30 min. Then, $500 \mu \mathrm{L}$ of cold $\left(-20{ }^{\circ} \mathrm{C}\right)$ chloroform-octanol (24:1) was added and centrifuged for $5 \mathrm{~min}$ at $6000 \mathrm{~g}$. Next, the top phase was extracted to which was added $350 \mu \mathrm{L}$ of chloroform-octanol (24:1). Centrifugation was repeated and once again the top phase was extracted to which $175 \mu \mathrm{L}$ of ammonium acetate $7.5 \mathrm{M}$ and $370 \mu \mathrm{L}$ of cold isopropanol were added. These reagents were mixed by inversion and left to precipitate all night at $4{ }^{\circ} \mathrm{C}$. Subsequently, they were centrifuged for $30 \mathrm{~min}$ at 13600 $\mathrm{g}$ and the DNA precipitate was washed with $500 \mu \mathrm{L}$ of cold ethanol, followed by another centrifugation (13 $600 \mathrm{~g}$; 5 $\mathrm{min}$ ) with the ethanol being eliminated after each washing. Finally, the precipitate formed was left to dry at room temperature for $30 \mathrm{~min}$ and was resuspended in $100 \mu \mathrm{L}$ of sterile distilled water.

DNA quantification was carried out with a spectrophotometer (Nanodrop ND-1000, Wilmington, Delaware, USA) and its quality was verified by PCR for the ITS regions (present in the plants), using the ITS 3 and ITS4 primers (Van der Stappen et al., 1998).

To determine the presence of phytoplasmatic DNA, a preamplification was performed with a pair of universal primers for phytoplasmas (PA2F: 5'gccecggctaactatgtgc 3'; PA2R: 5' ttggtgggcctaaatggactc 3') (Heinrich et al., 2001). A nested-PCR was carried out from this first reaction using a new pair of primers with greater specificity and sensitivity (NPA2F: 5' atgacetgggctacaaacgtga 3'; NPA2R: 5' ggtgggectaaatggactcg 3') that magnified a region of $485 \mathrm{bp}$ which corresponds to position 1182 of the 16S rRNA gene and 1667 of the intergenic region between the 16S-23S rRNA genes (Heinrich et al., 2001). Preamplification was performed in a volume of $25 \mu \mathrm{L}$ per sample, divided into: $2.5 \mu \mathrm{L}$ of PCR 10x buffer; $1.0 \mu \mathrm{L}$ of $\mathrm{MgCl}_{2}(25 \mathrm{mM}) ; 0.5 \mu \mathrm{L} \mathrm{dNTP}(2 \mathrm{mM}) ; 0.5 \mu \mathrm{L}$ of each primer $\left(10\right.$ pmol $\left.\mu \mathrm{L}^{-1}\right) ; 0.2$ taq ADN polymerase $\left(5 \mathrm{U}_{\mu \mathrm{L}^{-1}}\right.$, Fermentas Inc., Glen Burnie, Maryland, USA), $18.8 \mu \mathrm{L}$ sterile distilled water with $1.5 \% \mathrm{PVP}$, and $1 \mu \mathrm{L}$ of DNA (25 ng $\mu \mathrm{L}^{-1}$ ). The thermal profile of the 35 cycles of the PCR (MJ Research, PTC-100 Thermal Cycler) consisted in denaturalization at $94{ }^{\circ} \mathrm{C}$ for $1 \mathrm{~min}(3 \mathrm{~min}$ for the first cycle), alignment at $60^{\circ} \mathrm{C}$ for $1 \mathrm{~h} 15 \mathrm{~min}$, and elongation at $72{ }^{\circ} \mathrm{C}$ for $1 \mathrm{~h} 30 \mathrm{~min}$ (10 min for the last cycle). For the nested-PCR, basically the same preamplification conditions were used, only changing the primers and eliminating PVP. For this magnification, 40 cycles were carried out at $94{ }^{\circ} \mathrm{C}$ for $1 \mathrm{~min}$ ( $3 \mathrm{~min}$ for the first cycle), $60{ }^{\circ} \mathrm{C}$ for $50 \mathrm{~s}$, and $72{ }^{\circ} \mathrm{C}$ for $1 \mathrm{~h} 30 \mathrm{~min}(7 \mathrm{~min}$ for the final elongation). Phytoplasmatic DNA was used as a positive control (ACLR-AY isolate provided by N. Fiore, Universidad de Chile).

Products of the PCR reaction were run in $1 \%$ agarose gels with $0.1 \mu \mathrm{L} \mathrm{mL}^{-1}$ of ethyl bromide in an SB buffer (Brody and Kern, 2004) at $100 \mathrm{~V}$ for $30 \mathrm{~min}$. Subsequently, the amplicons were observed and photographed on a UV light transilluminator.

TheDNAmagnified by PCR was purified and sequenced (Macrogen, Seoul, South Korea) using the modified Tint primer (Smart et al., 1996) (5' aggcgtgtgctctaac 3') to avoid sequencing of contaminating DNA. Phytoplasma sequences obtained from chaura and murta were recorded in the database of the European Bioinformatics Institute (EBI, Cambridge, UK) as the accession numbers AM980866 and FM200179, respectively. These sequences were compared and identified (FASTA-EBI) with others in the EBI database. The dendrogram was constructed with the ClustalX program by the neighborjoining method with 1000 bootstraps to relate 17 phytoplasmatic sequences involving 15 groups classified on the basis of the 16S rRNA gene according to IRPCM Phytoplasma/Spiroplasma Working Team-Phytoplasma Taxonomy Group (2004). To achieve a valid comparison, the 17 sequences were reduced to the longitude of the isolated sequences in this study. Acholeplasma laidlawii (Mollicutes) was used as the dendrogram root.

\section{RESULTS AND DISCUSSION}

\section{DAPI staining}

U. molinae and G. phillyreifolia plant samples presenting symptoms of witches' broom showed a high concentration of fluorescent bodies in the phloem cells (Figure 1). Small points and aggregations near the cell wall in the cells of the conductor tissue were observed. On the contrary, tissues of plants without symptoms of the disease did not present fluorescence in the phloematic cells.

DAPI is a low cost and rapid method for detecting phytoplasmatic bodies in different plant tissues, but is not a specific tool since it can stain DNA of other microorganisms or organelles such as mitochondria and chloroplasts (Fránová et al., 2007). Therefore, this technique has only been used as a preliminary diagnostic tool and is mainly complemented by PCR (Jarausch et al., 1998; Cordova et al., 2003; Bricker and Stutz, 2004; Canik and Ertunc, 2007).

\section{PCR}

Amplification of the ITS region allowed satisfactorily copying the plant DNA fragment (500 bp) in all the $U$. molinae and G. phillyreifolia samples evaluated (Figure 2A). This control was essential to verify the absence of inhibitors of the PCR reaction such as polysaccharides and/ or phenolic compounds, habitual resistance components in plants suffering some kind of stress due to pathogens (Lherminier et al., 2003). 


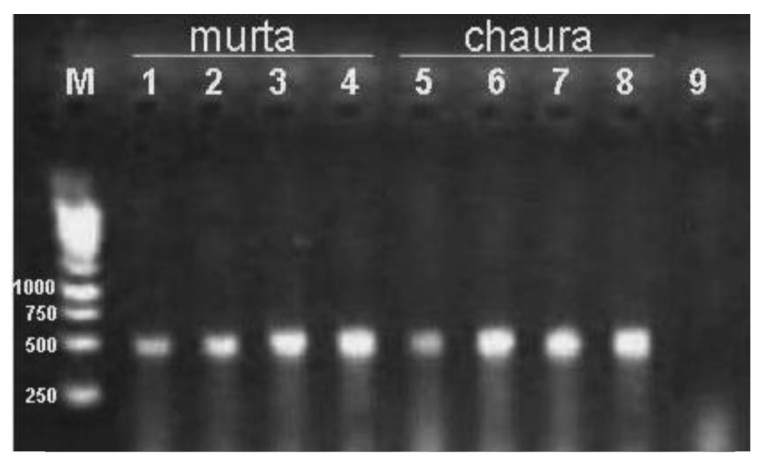

A

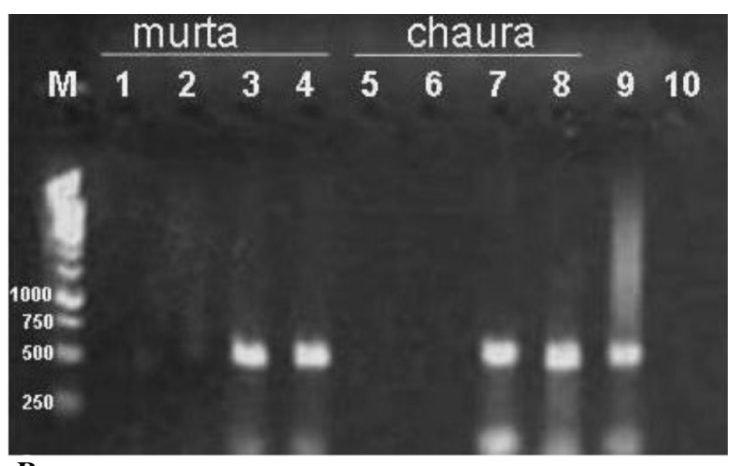

B

Figure 2. Electrophoresis in agarose gels (1\%) of amplified DNA samples of the ITS region (A) and 16S-23S rRNA with universal primers for phytoplasma (nested-PCR) in murta (Ugni molinae) and chaura (Gaultheria phillyreifolia) (B). A: Molecular weight markers (1 kb) $(\mathrm{M})$, asymptomatic samples (1 and 2) and with symptoms of witches' broom in murta (3 and 4), asymptomatic samples (5 and 6) and with symptoms of witches' broom in chaura (7 and 8 ), polymerase chain reaction (PCR) without DNA (C-) (9). B: Molecular weight (1 kb) (M), asymptomatic samples (1 and 2) and with symptoms of witches' broom in murta (3 and 4), Asymptomatic samples (5 and 6) and with symptoms of witches' broom in chaura (7 and 8), phytoplasma DNA $(C+)(9)$, and PCR reaction without DNA (C-) (10).

No phytoplasmatic DNA amplicons were achieved in preamplification (first PCR reaction) in the murta, chaura, and positive control samples evaluated. However, carrying out a nested-PCR (second PCR reaction) allowed obtaining DNA bands of an approximate length of $485 \mathrm{bp}$ (Figure 2B) for the samples that presented symptoms of witches' broom. A fragment of similar size was observed for the positive control of phytoplasmas. On the other hand, no DNA bands were visualized in the asymptomatic tissue samples (Figure 2B).

The fact that the detection of phytoplasmatic DNA was achieved only with a nested-PCR is attributable to its low concentrations as compared to plant DNA and the possible presence of remains of the PCR inhibitor compounds (Green et al., 1999; Khan et al., 2004). In the second PCR reaction, conditions are optimized and the sensitivity of the technique is increased (Berges et al., 2000) facilitating visualization of the amplicons.

\section{Sequencing and identification}

DNA sequences between 392 and 416 bp (accession numbers FM200179 in U. molinae and AM980866 in G. phillyreifolia) were obtained with the sequencing of the amplicons generated from the diseased tissue of both species. Both sequences showed a $100 \%$ homology one with the other, as well as high homologies with other phytoplasma sequences. Alignment and construction of the dendrogram with sequences from the 16S rRNA gene and part of the 16S-23S rRNA intergenic region of 17 phytoplasmas allowed relating the derived phytoplasma sequences of murta and chaura (from now on referred to as Chilean shrub witches' broom phytoplasma) in the ash yellows group (16SrVII) (Figure 3). These partial sequences were highly similar $(99.8 \%)$ to Candidatus Phytoplasma fraxini, and to a lesser degree with Erigeron witches' broom phytoplasma (97.3\%) (accession number AY034608), and Argentinean alfalfa witches' broom phytoplasma (95.1\%) (accession number AY147038); all of which are from the ash yellows group.

These results confirm the preliminary evaluations carried out with DAPI, indicating that the observation of fluorescence in the phloematic tissues coincides with the presence of phytoplasmas, similar to another works made on other species (Cordova et al., 2003; Bricker and Stutz, 2004; Canik and Ertunc, 2007; Fránová et al., 2007). This is one of the first reports of the detection and identification of native plant phytoplasmas in Chile. Previously, with the help of electronic microscopy and PCR, witches' broom disease had been associated to phytoplasmas in $U$. molinae, but without identifying them (Villagra, 2001). In G. phillyreifolia, no report had been presented indicating the nature of the causal agent in the witches' broom symptomatology. Both chaura and murta are shrubs that grow together in southern Chile, situation benefiting the mixed infection of the phytoplasma since recent studies have demonstrated that the Carelmapu ramosi Linnovuori \& DeLong (Cicadellidae) insect is related as the principal vector of the phytoplasma associated with witches' broom disease in G. phillyreifolia (Arismendi et al., 2008). The same species of insect had already been identified as one of the possible vectors of phytoplasma in murta (Miño, 2003), circumstance favoring the plant-phytoplasmainsect interaction. 

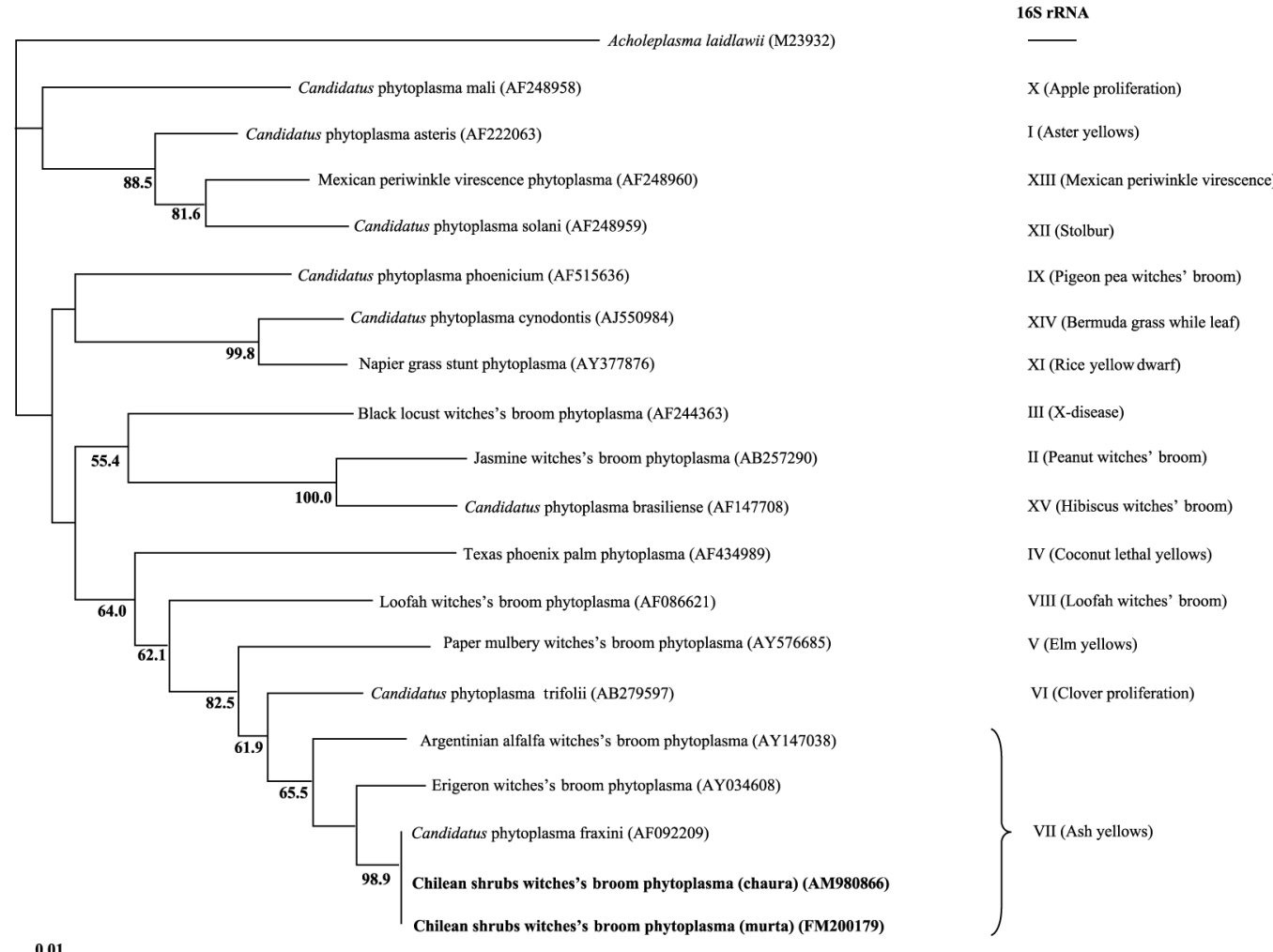

Figure 3. Dendrogram constructed by the neighbor-joining method with 17 partial sequences of 16S rRNA gene from phytoplasmas. Acholeplasma laidlawii was used as the outgroup and numbers of each branch indicate bootstrap values $(>\mathbf{5 0} \%)$. Roman numerals indicate phytoplasmatic group according to the IRPCM Phytoplasma/Spiroplasma Working Team-Phytoplasma Taxonomy Group (2004).

Phytoplasmas of the ash yellows group (16SrVII) in America have been detected in different hosts and mainly related to diseases of the witches' broom type (Griffiths et al., 1999; Feeley et al., 2001; Barros et al., 2002; Conci et al., 2005). Within the ash yellows group, phytoplasmas reported in Argentina (Argentinean witches' broom phytoplasma) and Brazil (Erigeron witches' broom phytoplasma) are associated with the 16SrVII-C and 16SrVII-B subgroups, respectively (Barros et al., 2002; Conci et al., 2005). The high bootstrap (98.9\%) generated in the dendrogram suggests that Chilean shrub witches' broom phytoplasma is related more to the Candidatus Phytoplasma fraxini (16SrVII-A) than to the two previously mentioned subgroups (Figure 3). Recent studies in Chile have reported the presence of phytoplasmas of the 16SrVII-A subgroup associated with yellow grapevine disease (Fiore et al., 2007). However, it is still not possible to determine with the currently available information if native species such as chaura and murta could act as important phytoplasma reservoirs for other economically important crops. Furthermore, future research should establish the aspects of temporal and spatial dispersion of this type of phytoplasma, aspect associated with the feeding habit and distribution of the insect vector(s).

\section{CONCLUSIONS}

Microscopic evidence (DAPI staining) and molecular evidence (PCR and DNA sequencing) indicate that witches' broom disease in $U$. molinae and en $G$. phillyreifolia is associated with a phytoplasma within the ash yellows group (16SrVII), relating that sequences more with the 16SrVII-A subgroup than to the other two subgroups reported on.

\section{ACKNOWLEDGEMENTS}

This research was financed by Project DID S-20066 of the Universidad Austral de Chile. We are grateful to Nicola Fiore of the Universidad de Chile for providing the phytoplasmatic positive control $(\mathrm{C}+)$. 


\section{RESUMEN}

Presencia de un fitoplasma asociado a la enfermedad de "escoba de bruja" en Ugni molinae Turcz. y Gaultheria phillyreifolia (Pers.) Sleumer determinado mediante DAPI, PCR y secuenciación de ADN. La murta (Ugni molinae Turcz.) y la chaura común (Gaultheria phillyreifolia (Pers.) Sleumer) son especies nativas de Chile. En plantas de ambas especies se ha observado una sobre-ramificación de tipo "escoba de bruja". En muchas plantas los agentes causales de esta sintomatología son fitoplasmas. Para verificar la presencia de estos microorganismos se analizaron plantas con y sin síntomas mediante tinciones DAPI (4',6-diamidino-2-fenilindol) y reacción en cadena de la polimerasa (PCR). Muestras positivas en la PCR fueron secuenciadas para identificar al fitopatógeno implicado. En individuos de ambas especies con síntomas de escoba de bruja, la tinción DAPI permitió observar cuerpos fluorescentes en los tejidos del floema, situación que no ocurrió en plantas asintomáticas. En la verificación mediante PCR-anidada, se logró amplificar ADN fitoplasmático en plantas de murta y chaura enfermas, pero no en plantas aparentemente sanas. La secuenciación de los productos amplificados permitió localizar al fitoplasma dentro del grupo "ash yellows" (16SrVII) y relacionado al "Candidatus Phytoplasma fraxini". Éste es el primer reporte que caracteriza a un fitoplasma en especies nativas chilenas. Considerando la diversidad de especies de plantas infectadas por el grupo ash yellows, sugiere que $G$. phillyreifolia y $U$. molinae podrían constituir un reservorio de fitoplasmas para otros cultivos agrícolas de importancia económica.

Palabras clave: arbustos nativos, escoba de bruja, fitoplasma, técnicas microscópicas y moleculares.

\section{LITERATURE CITED}

Abou-Jawdah, Y., A. Karakashian, H. Sobh, M. Martini, and I-M. Lee. 2002. An epidemic of almond witches' broom in Lebanon: Classification and phylogenetic relationships of the associated phytoplasma. Plant Dis. 86:477-484.

Al-Zadjalt,A., T. Natsuaki, and S. Okuda. 2007. Detection, identification and molecular characterization of a phytoplasma associated with Arabian jasmine (Jasminum sambac L.) witches' broom in Oman. Phytopathology 155:211-219.
Arismendi, N., N. Andrade, R. Riegel, y R. Carrillo. 2008. Identificación del candidato a vector del fitoplasma causante de la "escoba de bruja" en Gautheria phillyreifolia (Pers.) Sleumer utilizando PCR y secuenciación de ADN. p. 73. In $59^{\circ}$ Congreso Agronómico de Chile y $9^{\circ}$ Congreso de la Sociedad Chilena de Fruticultura, La Serena. 07-10 de octubre de 2008. Sociedad Agronómica de Chile, Santiago, Chile.

Barros, T.S., R.E. Davis, R.O. Resende, and E.L. Dally. 2002. Erigeron witches' broom phytoplasma in Brazil represents new subgroup VII-B in 16S rRNA gene group VII, the ash yellows phytoplasma group. Plant Dis. 86:1142-1148.

Berges, R., M. Rott, and E. Seemüller. 2000. Range of phytoplasma concentrations in various plant hosts as determined by competitive polymerase chain reaction. Phytopathology 90:1145-1152.

Bertaccini, A. 2007. Phytoplasmas: diversity, taxonomy, and epidemiology. Front. Biosci. 12:673-689.

Bricker, J.S., and J.C. Stutz. 2004. Phytoplasmas associated with ash decline. J. Arboric. 30:193-199.

Brody, J.R., and S.E. Kern. 2004. Sodium boric acid: a Tris-free, cooler conductive medium for DNA electrophoresis. BioTechniques 36:214-216.

Canik, D., and F. Ertunc. 2007. Distribution and molecular characterization of apple proliferation phytoplasma in Turkey. Bull. Insectol. 60:335-336.

Chapman, G.B., E.J. Buerkle, E.M. Barrows, R.E. Davis, and E.L. Dally. 2001. A light and transmission electron microscope study of a black locust tree, Robinia pseudoacacia (Fabaceae), affected by witches' broom, and classification of the associated phytoplasma. J. Phytopathol. 149:589-597.

Conci, L., N. Meneguzzi, E. Galdeano, L. Torres, C. Nome, and S. Nome. 2005. Detection and molecular characterisation of an alfalfa phytoplasma in Argentina that represents a new subgroup in the $16 \mathrm{~S}$ rDNA ash yellows group ('Candidatus Phytoplasma fraxini'). Eur. J. Plant Pathol. 113:255-265.

Cordova, I., P. Jones, N. Harrison, and C. Oropeza. 2003. In situ PCR detection of phytoplasma DNA in embryos from coconut palms with lethal yellowing disease. Mol. Plant Pathol. 4:99-108.

Delporte, C., N. Backhouse, V. Inostroza, M.C. Aguirre, N. Peredo, X. Silva, et al. 2007. Analgesic activity of Ugni molinae (murtilla) in mice models of acute pain. J. Ethnopharmacol. 112:162-165.

Donoso, C., y C. Ramírez. 1997. Arbustos nativos de Chile: Guía de reconocimiento (Chilean bushes: Identification guide). Vol. 2. 116 p. $3^{\mathrm{a}}$ ed. Marisa Cúneo Ediciones, Valdivia, Chile. 
Feeley, C.J., E.R. Hart, J.R. Thompson, and T.C. Harrington. 2001. Occurrence, associated symptoms, and potential insect vectors of the ash yellows phytoplasma in Iowa, U.S. J. Arboric. 27:331-340.

Fiore, N., S. Prodan, S. Paltrinieri, A. Gajardo, S. Botti, A.M. Pino, et al. 2007. Molecular characterization of phytoplasmas in Chilean grapevines. Bull. Insectol. 60:331-332.

Fránová, J., K. Petrzik, F. Paprštein, J. Kučerová, M. Navrátil, P. Válová, et al. 2007. Experiences with phytoplasma detection and identification by different methods. Bull. Insectol. 60:247-248.

Ghosh, D., A. Das, S. Singh, S. Singh, and Y. Ahlawat. 1999. Association of a phytoplasma with witches' broom, a new disease of acid lime (Citrus aurantifolia). Curr. Sci. 77:174-177.

Green, M.J., D.A. Thompson, and D.J. MacKenzie. 1999. Easy and efficient DNA extraction from woody plants for the detection of phytoplasma by polymerase chain reaction. Plant Dis. 83:482-485

Griffiths, H.M., W.A. Sinclair, C.D. Smart, and R.E. Davis. 1999. The phytoplasma associated with ash yellows and lilac witches' broom: 'Candidatus Phytoplasma fraxini’. Int. J. Syst. Bacteriol. 49:1605-1614.

Heinrich, M., S. Botti, L. Caprara, W. Arthrofer, S. Strommer, V. Hanzer, et al. 2001. Improved detection method for fruit tree phytoplasmas. Plant Mol. Biol. Rep. 19:169-179.

Hepp, R., C. Sandoval, J. Romero, y S. Castro. 1998. Detección de un fitoplasma en manzanos con síntomas de Rubbery Wood mediante la reacción en cadena de la polimerasa (PCR). p. 38. In VIII Congreso Nacional de Fitopatología, Chillán. 28-30 de octubre de 1998. Sociedad Chilena de Fitopatología, Santiago, Chile.

Hepp, R., y M. Vargas. 2002. Detección por PCR del agente causal de la marchitez amarilla de la remolacha en cicadélidos (Homóptera: Cicadellidae) asociados al cultivo de la remolacha. Fitopatología 37:67-108.

Herrera, G., y M. Madariaga. 2003. Evidencias inmunológicas, microscópicas y moleculares de la presencia de fitoplasmas en vides. Agric. Téc. (Chile) 63:15-22.

IRPCM Phytoplasma/Spiroplasma Working TeamPhytoplasma Taxonomy Group. 2004. "Candidatus Phytoplasma", a taxon for the wall-less, non-helical prokariotes that colonize plant phloem and insects. Int. J. Syst. Evol. Microbiol. 54:1243-1255.

Jarausch, W., M. Lansac, C. Saillard, J.M. Broquaire, and F. Dosba. 1998. PCR assay for specific detection of European stone fruit yellows phytoplasmas and its use for epidemiological studies in France. Eur. J. Plant Pathol. 104:17-27.
Khan, A.J., S. Botti, A.M. Al-Subhi, D.E. GundersenRindal, and A.F. Bertaccini. 2002. Molecular identification of a new phytoplasma associated with alfalfa witches' broom in Oman. Phytopathology 92:1038-1047.

Khan, J., P. Srivastava, and K. Singh. 2004. Efficacy of nested-PCR for the detection of phytoplasma causing spike disease of sandal. Curr. Sci. 86:1530-1533.

Lee, I-M., R.E. Davis, and D.E. Gundersen-Rindal. 2000. Phytoplasma: Phytopathogenic Mollicutes. Annu. Rev. Microbiol. 54:221-255.

Lee, I.-M., D.E. Gundersen-Rindal, R.E. Davis, and I.M. Bartoszyk. 1998. Revised classification scheme of phytoplasmas based on RFLP analysis of $16 \mathrm{~S}$ rRNA and ribosomal protein gene sequences. Int. J. Syst. Bacteriol. 48:1153-1169.

Lherminier, J., N. Benhamou, J. Larrue, M.L. Milat, E. Boudon-Padieu, M. Nicole, and J.-P. Blein. 2003. Cytological characterization of elicitin-induced protection in tobacco plants infected by Phytophthora parasitica or phytoplasma. Phytopathology 93:13081319.

Lodhi, M.L., G.-N. Ye, N.F. Weeden, and B.I. Reisch. 1994. A simple and efficient method for DNA extraction from grapevine cultivars, Vitis species and Ampelopsis. Plant Mol. Biol. Rep. 12:6-13.

Marcone, C., K.S. Gibb, C. Streten, and B. Schneider. 2004. 'Candidatus Phytoplasma spartii', 'Candidatus Phytoplasma rhamni' and 'Candidatus Phytoplasma allocasuarinae', respectively associated with spartium witches' broom, buckthorn witches' broom and allocasuarina yellows diseases. Int. J. Syst. Evol. Microbiol. 54:1025-1029.

Matus, J.T., A. Vega, R. Loyola, C. Serrano, S. Cabrera, and P. Arce-Johnson. 2008. Phytoplasma and virus detection in commercial plantings of Vitis vinífera cv. Merlot exhibiting premature berry dehydration. Electron. J. Biotechnol. 11:1-10.

Miño, J. 2003. Identificación del vector del fitoplasma causante de la escoba de bruja en murta (Ugni molinae Turcz.). 98 p. Tesis de Licenciado en Agronomía. Universidad Austral de Chile, Facultad de Ciencias Agrarias, Valdivia, Chile.

Montano, H.G., R.E. Davis, E.L. Dally, S. Hogenhout, J.P. Pimentel, and P.S. Brioso. 2001. 'Candidatus Phytoplasma brasiliense', a new phytoplasma taxon associated with hibiscus witches' broom disease. Int. J. Syst. Evol. Microbiol. 51:1109-1118.

Romero, J. 2001. XI Curso Internacional Teórico-Práctico de Detección e Identificación de Virus, Viroides y Fitoplasmas. p. 2-9. Instituto Nacional de Investigación y Tecnología Agraria y Alimentaria (INIA), Madrid, España. 
Seguel, I., y L. Torralbo. 2004. Murtilla: El berry nativo del sur de Chile. Tierra Adentro $\mathrm{N}^{\circ}$ 57. p. 20-25.

Schneider, B., K.S. Gibb, and E. Seemüller. 1997. Sequence and RFLP analysis of the elongation factor Tu gene used in differentiation and classification of phytoplasmas. Microbiology 143:3381-3389.

Smart, C.D., B. Schneider, C.L. Blomquist, L.J. Guerra, N.A. Harrison, U. Ahrens, et al. 1996. Phytoplasmaspecific PCR primers based on sequences of the 16S-23S rRNA spacer region. Appl. Environ. Microbiol. 62:2988-2993.

Suwalsky, M., P. Orellana, M. Avello, and F. Villena. 2007. Protective effect of Ugni molinae Turcz. against oxidative damage of human erythrocytes. Food Chem. Toxicol. 45:130-135.
Van der Stappen, J., S. Van Campenhout, S.G. López, and G. Volkaert. 1998. Sequencing of the internal transcribed spacer region ITS1 as a molecular tool detecting variation in the Stylosanthes guianensis species complex. Theor. Appl. Genet. 96:869-877.

Villagra, M. 2001. Identificación del agente causal de escoba de bruja en murta (Ugni molinae Turcz.) 95 p. Tesis de Licenciado en Agronomía. Universidad Austral de Chile, Facultad de Ciencias Agrarias, Valdivia, Chile.

Weintraub, P., and L. Beanland. 2006. Insect vectors of phytoplasmas. Annu. Rev. Entomol. 51:91-111. 